\title{
TWO METHODS FOR CONSTRUCTION OF SUBOPTIMISTIC AND SUBPESSIMISTIC SOLUTIONS OF THE INTERVAL PROBLEM OF MIXED-BOOLEAN PROGRAMMING
}

Mamedov K. Sh. - Dr. Sc., Professor of Baku State University and head of Department of the Institute of Control Systems of the National Academy of Sciences of Azerbaijan, Azerbaijan, Baku.

Mammadli N. O. - Doctorant, Institute of Control Systems, Azerbaijan National Academy of Sciences, Baku, Azerbaijan.

\begin{abstract}
Context. The interval problem of mixed Boolean programming having numerous economic applications is considered. The object of the study was a model of the integer programming.

Objective. Development of methods for constructing suboptimistic and subpessimistic solutions of the mixed Boolean programming interval problem.

Two methods for constructing suboptimistic and subpessimistic solutions of mixed Boolean programming problems with interval initial data are introduced. These methods are based on some economic interpretation of the model considered.

Method. Two methods for constructing suboptimistic and subpessimistic solutions of mixed Boolean programming problems with interval initial data are introduced. These methods are based on some economic interpretation of the considered model. In the first method a criterion of selecting unknowns for assigning values, which is based on the principle of profit maximum for each unit of expenditure is introduced. Since the coefficients of the problem are intervals, two strategies are chosen: optimistic and pessimistic. In the optimistic strategy, the idea of choosing unknowns is used, which corresponds to the maximum ratio of the corresponding maximum profit to the minimum expenditure. And in the pessimistic strategy, the idea of maximum ratio of the minimum profit to the maximum expenditure is used. In the second method, the concept of a non-linearly increasing penalty (price) for using a unit of the remaining resources is introduced, that on the right side is bounded. Taking into account the principles of the above first and second methods, using this concept of penalty (price), methods for constructing suboptimistic and subpessimistic solutions have been developed.

Results. The algorithms for constructing suboptimistic and subpessimistic solutions to the interval problem of mixed Boolean programming are developed.

Conclusions. A software package was developed for constructing suboptimistic and subpessimistic solutions to the interval problem of mixed Boolean programming. A number of computational experiments have been carried out over random problems of various dimensions.

KEYWORDS: an interval problem of mixed Boolean programming, optimistic, pessimistic, sub-optimistic and sub-pessimistic solutions, upper and lower bounds, errors, experiments.
\end{abstract}

\section{NOMENCLATURE}

$N$-the number of all variables,

$n$ - the number of boolean variables,

$m$ - number of bounders,

$I=[1, \ldots, n]-$ set of indexes of variables, taking boolean values;

$R=[n+1, n+2, \ldots, N]-$ set of indexes of variables, taking continuous values;

$\underline{c}_{j}, \bar{c}_{j}, \underline{a}_{i j}, \bar{a}_{i j}, \underline{b}_{i}, \bar{b}_{i}$ - given positive integers;

$j_{*}-$ fixed item;

$x_{j}-j$-th unknown;

$X-N$-dimensijnal vector;

$X^{\text {op }}$ - an optimistic solution;

$f^{o p}$ - an optimistic value;

$X^{p}-$ a pessimistic solution;

$f^{p}-$ a pessimistic value;

$\bar{q}_{i}, \underline{q}_{i}-$ a penalty (price) for using the $i$-th resource for the optimistic and pessimistic solutions, respectively; $\bar{r}_{i}, \underline{r}_{i}-$ use of the $i$-th resource for the optimistic and pessimistic solutions, respectively;

$\bar{Q}_{j}, \underline{Q}_{j}$ - the total penalty for using the remaining resources for the unknowns $x_{j}$ for an optimistic and pessimistic solutions, respectively;

$\bar{f}_{o p}, \bar{f}_{p}$ - upper bounds of the suboptimistic and subpessmistic values of the objective function, respectively;

$$
f_{\text {so }}^{1}, f_{\text {so }}^{2}, f_{\text {so.sht }}^{1}, f_{\text {so.sht }}^{2}, \quad f_{s p}^{1}, f_{\mathrm{sp}}^{2}, f_{s p . s h t}^{1}, f_{s p . s h t}^{2}
$$

suboptimistic and subpessimistic values of the objective function obtained by the 1-st and 2-nd methods (non-linearly increasing penalty) corresponding to the 1-st and 2-nd approaches;

$$
\begin{aligned}
& X^{s o} \text { - a suboptimistic solution; } \\
& f^{s o} \text { - a suboptimistic value; } \\
& X^{s p} \text { - a suppessimistic solution; } \\
& f^{s p}-\text { a subpessimistic value; } \\
& \delta_{\text {so }}^{1}, \delta_{\mathrm{so}}^{2}, \delta_{\text {so.sht }}^{1}, \delta_{\mathrm{so.sht}}^{2}, \delta_{\mathrm{sp}}^{1}, \delta_{\mathrm{sp}}^{2}, \delta_{\mathrm{sp} . s h t}^{1}, \delta_{\mathrm{sp} . \mathrm{sht}}^{2}-\text { rela- }
\end{aligned}
$$
tive errors of the suboptimistic and subpessimistic values of 
the objective function from the optimistic and pessimistic values obtained by the 1-st and 2-nd methods (non-linearly increasing penalty) corresponding to the 1-st and 2-nd approaches;

$k_{\text {so }}, k_{\text {so.sht }}, k_{\text {sp }}, k_{\text {sp.sht }}-$ the number of remaining continuous variables after the application of the 1-st and 2-nd methods (nonlinearly increasing penalty) with the second approach for construction suboptimistic and subpessimistic solutions, respectively.

\section{INTRODUCTION}

At the begining of the mixed Boolean programming problems with interval data, we give some economic interpretation.

Let there are many objects. Some of these objects can be used or ignored, and the rest of the objects can be used to some extent. Suppose for the use of these objects, the resources belonging to a certain interval were distinguished.

If a fixed object is selected for use (or partial use), then the possible costs will be within the specified interval.

In this case, the profit also belongs to a given other interval. It is required to choose for use (or partial use) such objects, the total costs of which do not exceed the allocated resources included in the corresponding intervals, and the total profit will be maximum. Taking the corresponding variables, we obtain a mathematical model of mixed-Boolean programming with the interval initial data. Here the aim is to develop methods for solving of the obtained problem, taking into account the basic properties of the model. In addition, carry out comparative computational experiments to identify the quality of the developed methods.

\section{PROBLEM STATEMENT}

The following problem is considered:

$$
\begin{gathered}
\sum_{j=1}^{n}\left[\underline{c}_{j}, \bar{c}_{j}\right] x_{j}+\sum_{j=n+1}^{N}\left[\underline{c}_{j}, \bar{c}_{j}\right] x_{j} \rightarrow \max \\
\sum_{j=1}^{n}\left[\underline{a}_{i j}, \bar{a}_{i j}\right] x_{j}+\sum_{j=n+1}^{N}\left[\underline{a}_{i j}, \bar{a}_{i j}\right] x_{j} \leq\left[\underline{b}_{i}, \bar{b}_{i}\right],(i=\overline{1, m}), \\
0 \leq x_{j} \leq 1,(j=\overline{1, N}), \\
x_{j}=1 \vee 0,(j=\overline{1, n}),(n \leq N) .
\end{gathered}
$$

Here it is assumed that $\underline{c}_{j}>0, \bar{c}_{j}>0, \underline{a}_{i j} \geq 0, \bar{a}_{i j} \geq 0, \underline{b}_{i}>0$,

$\bar{b}_{i}>0(i=\overline{1, m}, j=\overline{1, N})$ are given integers.

We note the following natural conditions for the coefficients of the problem (1)-(4). First, for each conditions must be satisfied $\sum_{j=1}^{N} \underline{a}_{i j}>\bar{b}_{i},(i=\overline{1, m})$.

(C) Mamedov K. Sh., Mammadli N. O., 2018 DOI 10.15588/1607-3274-2018-3-7
Conversely, if for all these conditions are not satisfied, then the solution $X=(1,1,1, \ldots, 1)$ will satisfy the system (2)(4) and it will be the optimal solution. On the other hand, if for some fixed $i_{*}$ the condition $\sum_{j=1}^{N} \bar{a}_{i_{*} j} \leq \underline{b}_{i_{*}},(i=\overline{1, m})$ is fulfilled then the inequality $i_{*}$ is not a restriction and it is excluded from the system (2). We assume that the above natural conditions are fulfilled for the problem (1)-(4).

This problem is called the problem of mixed-Boolean programming with interval data or simply the interval problem of mixed-Boolean programming. The considered problem (1)-(4) is a generalization of the Boolean programming problems, interval Boolean programming problems, and linear programming problems. In the case of $n=0$ we obtain the linear programming problem with interval data, in the case of $n=N$ an interval Boolean programming problem is obtained, in the case of $\underline{c}_{j}=\bar{c}_{j}, \underline{a}_{i j}=\bar{a}_{i j}, \underline{b}_{i}=\bar{b}_{i},(i=\overline{1, m}, j=\overline{1, N})$ the well-known Boolean or mixed-Boolean programming problem is obtained.

In the beginning, for problems (1)-(4) we give some economic interpretation. Let there are $N$ objects. From each object $n(n \leq N)$ you can use or ignore, and for other objects $N-n$ you can use to some extent. Assume that the resources included in the interval $\left[\underline{b}_{i}, \bar{b}_{i}\right](i=\overline{1, m})$ are allocated to use these objects. If the $j$-th object $(j=\overline{1, N})$ is selected for use (or partial use), then the possible costs enter the interval $\left[\underline{a}_{i j}, \bar{a}_{i j}\right](i=\overline{1, m} ; j=\overline{1, N})$, while the profit belongs to the interval $\left[\underline{c}_{j}, \bar{c}_{j}\right](j=\overline{1, N})$.

It is required to choose for use (or partial use) such objects, which total costs did not exceed the allocated resources involved in the interval $\left[\underline{b}_{i}, \bar{b}_{i}\right](i=\overline{1, m})$, and the total profit was maximum. Obviously, taking variables $x_{j}=\left\{\begin{array}{l}1, \text { if } j \text {-th object is taken } \\ 0, \text { otherwise, }(j=\overline{1, n}),\end{array}\right.$ and $0 \leq x_{j} \leq 1,(j=\overline{n+1, N})$, then the mathematical model of the problem will be in the form (1)-(4).

To construct solutions for problem (1)-(4), we have introduced two criteria for choosing the number of unknowns and assigning specific values. Based on these criteria, two methods for constructing solutions have been developed.

\section{LITERATURE REVIEW}

It should be noted that since all the particular cases of problem (1)-(4) are in NP-complete class, this problem also belongs to the class NP-complete; difficult-solvable [1-2]. As far as we know, the interval problem of mixed Boolean programming has not yet been investigated. In spite of this, some classes of interval integer-programming problems were investigated in [3-6].

In this article, for the problem (1)-(4), the concepts of admissible, optimistic, pessimistic, suboptimistic and sub- 
pessimistic solutions are introduced and methods for their solution are developed. These concepts are an extension of the concepts introduced in $[7,8]$. It should be noted that a number of approximate and exact algorithms for solving the classical Boolean programming problem are presented in $[9,10]$. And in [11] specific methods for construction of a suboptimal (or approximate) solution of Boolean programming problems were developed. The basic principles of interval calculus are presented in [12]. It should be noted that the concepts of a linearly-increasing penalty to construct an approximate Boolean programming solution were introduced in [13]. And in this paper a more powerful criterion is introduced, which we call a nonlinearly-increasing penalty for a more general class of problems.

\section{MATERIALS AND METHODS}

First we introduce an analog of the concepts introduced by the authors in $[7,8]$ for a more general class of mixed Boolean programming problems.

Definition 1. $N$-dimensional vector $X=\left(x_{1}, \ldots, x_{N}\right)$ satisfying the system of conditions (2)-(4) for $\forall a_{i j} \in\left[\underline{a}_{i j}, \bar{a}_{i j}\right]$ and $\forall b_{i} \in\left[\underline{b}_{i}, \bar{b}_{i}\right]$, $(i=\overline{1, m} ; j=\overline{1, N})$ is called an admissible solution of problem (1)-(4).

From this definition it immediately follows that the concepts of the optimal solution and the optimal value of the function (1) must have a different meaning, in contrast to the known ones. Because it is necessary to ensure that the sum of some intervals is not exceeded from a given specific interval $\left[\underline{b}_{i}, \bar{b}_{i}\right]$ and that the maximum of some other intervals is reached. To this end, we introduce a few more definitions.

Definition 2. An admissible solution $X^{o p}=\left(x_{1}^{o p}, x_{2}^{o p}, \ldots, x_{N}^{o p}\right)$, is called to be an optimistic solution of problem (1)-(4) if that satisfies the inequalities $\quad \sum_{j=1}^{N} \underline{a}_{i j} x_{j}^{o p} \leq b_{i}, \quad$ for $\quad \forall b_{i} \in\left[\underline{b}_{i}, \bar{b}_{i}\right]$, $(i=\overline{1, m} ; j=\overline{1, N})$, and in this, the value of the function $f^{o p}=\sum_{j=1}^{N} \bar{c}_{j} x_{j}^{o p}$ will be maximal.

Definition 3. An admissible solution $X^{p}=\left(x_{1}^{p}, x_{2}^{p}, \ldots, x_{N}^{p}\right)$ is called to be a pessimistic solution of problem (1)-(4) if that satisfies the inequalities $\quad \sum_{j=1}^{N} \bar{a}_{i j} x_{j}^{p} \leq b_{i} \quad$ for $\quad \forall b_{i} \in\left[\underline{b}_{i}, \bar{b}_{i}\right]$, $(i=\overline{1, m} ; j=\overline{1, N})$, and in this, the value of the function $f^{p}=\sum_{j=1}^{N} \underline{c}_{j} x_{j}^{p}$ will be maximal.

(C) Mamedov K. Sh., Mammadli N. O., 2018 DOI 10.15588/1607-3274-2018-3-7
From these definitions it is clear that in order to find the optimistic and pessimistic solutions of problem (1)-(4) it is necessary to solve many problems of mixed-Boolean programming, which is included in the class of NP-complete ones. And this requires unreal time to find the solution of large size problems. Therefore, we have introduced the following concepts of suboptimistic and subpessimistic i.e. approximate solutions of problem (1)-(4) and have developed algorithms for finding them.

Definition 4. An admissible solution $X^{\text {so }}=\left(x_{1}^{\text {So }}, x_{2}^{\text {so }}, \ldots, x_{N}^{\text {So }}\right)$ is called to be a sub-optimistic solution of the problem (1)-(4) if that satisfies the conditions $\sum_{j=1}^{N} \underline{a}_{i j} x_{j}^{\text {so }} \leq b_{i}$ for $\forall b_{i} \in\left[\underline{b}_{i}, \bar{b}_{i}\right], \quad(i=\overline{1, m} ; j=\overline{1, N})$ and the value of the function $f^{S o}=\sum_{j=1}^{N} \bar{c}_{j} x_{j}^{\text {So }}$ will take a large value.

Definition 5. An admissible solution $X^{s p}=\left(x_{1}^{s p}, x_{2}^{s p}, \ldots, x_{N}^{s p}\right)$ is called to be a sub-pessimistic solution of the problem (1)-(4) if that satisfies the conditions $\sum_{j=1}^{N} \bar{a}_{i j} x_{j}^{s p} \leq b_{i}$ for $\forall b_{i} \in\left[\underline{b}_{i}, \bar{b}_{i}\right], \quad(i=\overline{1, m} ; j=\overline{1, N})$ and in this, the value of the function $f^{s p}=\sum_{j=1}^{N} \underline{c}_{j} x_{j}^{s p}$ will take a large value.

\section{Theoretical justification of the 1st method.}

Using the above economic interpretation of problem (1)(4) introduced in paragraph 1 , we derive the criterion of choosing unknowns for assigning specific values. Let the $j$ th object $(j=\overline{1, N})$ be selected for use (or partial use). Then, the necessary expenses should be included in the interval $\left[\underline{a}_{i j}, \bar{a}_{i j}\right](i=\overline{1, m} ; j=\overline{1, N})$. In this case, the obtained profit is included in the given interval $\left[\underline{c}_{j}, \bar{c}_{j}\right](j=\overline{1, N})$. Obviously, the profit per unit of consumption included in the interval $\left[\underline{a}_{i j}, \bar{a}_{i j}\right](i=\overline{1, m} ; j=\overline{1, N})$ will be at least

$$
\min _{i} \frac{\left[\underline{c}_{j}, \bar{c}_{j}\right]}{\left[\underline{a}_{i j}, \bar{a}_{i j}\right]}=\frac{\left[\underline{c}_{j}, \bar{c}_{j}\right]}{\max _{i}\left[\underline{a}_{i j}, \bar{a}_{i j}\right]}(j=\overline{1, N}) .
$$

From here it is directly visible that it is necessary to choose a number $j_{*}$, which is determined from the following conditions:

$$
\begin{gathered}
x_{j}=1 \vee 0,(j=\overline{1, n}),(n \leq N) . \\
\max _{j} \frac{\left[\underline{c}_{j}, \bar{c}_{j}\right]}{\max _{i}\left[\underline{a}_{i j}, \bar{a}_{i j}\right]}=\frac{\left[\underline{c}_{j_{*}}, \bar{c}_{j_{*}}\right]}{\max _{i}\left[\underline{a}_{i j_{*}}, \bar{a}_{i j_{*}}\right]} .
\end{gathered}
$$


Using the formula (5) and taking into account the above definitions 4 and 5, we obtain the following criteria for choosing the number $j_{*}$ of unknowns $x_{j}$ for construction of suboptimistic and subpessimistic solutions, respectively:

$$
\begin{aligned}
& j_{*}=\arg \max _{j} \frac{\bar{c}_{j}}{\max _{i} \underline{a}_{i j}} . \\
& j_{*}=\arg \max _{j} \frac{\underline{c}_{j}}{\max _{i} \bar{a}_{i j}} .
\end{aligned}
$$

Thus, to construct a suboptimistic solution, one can use criterion (6), and for a sub-pessimistic solution, (7). In this case, it is necessary to take into account the case in what interval is $j_{*}$ i.e. $j_{*} \in[1, \ldots, n] \equiv I \quad$ or $j_{*} \in[n+1, n+2, \ldots, N] \equiv R$.

Theoretical justification of the 2nd method (nonlinearly-increasing penalty method). We write the problem (1)-(4) in the following equivalent form for fixed $b_{i}, b_{i} \in\left[\underline{b}_{i}, \bar{b}_{i}\right],(i=\overline{1, m})$ :

$$
\begin{gathered}
\sum_{j=1}^{n}\left[\underline{c}_{j}, \bar{c}_{j}\right] x_{j}+\sum_{j=n+1}^{N}\left[\underline{c}_{j}, \bar{c}_{j}\right] x_{j} \rightarrow \max \\
\sum_{j=1}^{n}\left[\underline{\alpha}_{i j}, \bar{\alpha}_{i j}\right] x_{j}+\sum_{j=n+1}^{N}\left[\underline{\alpha}_{i j}, \bar{\alpha}_{i j}\right] x_{j} \leq 1,(i=\overline{1, m},), \\
0 \leq x_{j} \leq 1,(j=\overline{1, N}), \\
x_{j}=1 \vee 0,(j=\overline{1, n}),(n \leq N) .
\end{gathered}
$$

Here $\quad \underline{\alpha}_{i j}=\underline{a}_{i j} / b_{i}, \quad \bar{\alpha}_{i j}=\bar{a}_{i j} / b_{i}, \quad b_{i}:=1$, $(i=\overline{1, m} ; j=\overline{1, N})$. It is obvious, that $\underline{c}_{j}>0, \bar{c}_{j}>0$, $0 \leq \underline{\alpha}_{i j} \leq 1, \quad 0 \leq \bar{\alpha}_{i j} \leq 1, \underline{\alpha}_{i j} \geq 0, \bar{\alpha}_{i j} \geq 0,(i=\overline{1, m}, j=\overline{1, N})$.

Proceeding from problem (8)-(11), we construct the following problem (12)-(15) and (16)-(19) which we call optimistic and pessimistic, respectively.

$$
\begin{gathered}
\sum_{j=1}^{n} \bar{c}_{j} x_{j}+\sum_{j=n+1}^{N} \bar{c}_{j} x_{j} \rightarrow \max , \\
\sum_{j=1}^{n} \underline{\alpha}_{i j} x_{j}+\sum_{j=n+1}^{N} \underline{\alpha}_{i j} x_{j} \leq 1,(i=\overline{1, m}), \\
0 \leq x_{j} \leq 1,(j=\overline{1, N}), \\
x_{j}=1 \vee 0,(j=\overline{1, n}),(n \leq N) .
\end{gathered}
$$

$$
\begin{gathered}
\sum_{j=1}^{n} \underline{c}_{j} x_{j}+\sum_{j=n+1}^{N} \underline{c}_{j} x_{j} \rightarrow \max , \\
\sum_{j=1}^{n} \bar{\alpha}_{i j} x_{j}+\sum_{j=n+1}^{N} \bar{\alpha}_{i j} x_{j} \leq 1,(i=\overline{1, m}), \\
0 \leq x_{j} \leq 1,(j=\overline{1, N}), \\
x_{j}=1 \vee 0,(j=\overline{1, n}),(n \leq N) .
\end{gathered}
$$

For optimistic problems (12)-(15) below, a method for constructing suboptimistic solutions was developed. Similarly, it is possible to develop a method for constructing subpessimistic of solutions of problems (16)-(19).

The process of constructing of a suboptimistic solution begins from an admissible solution $X^{s o}=(0,0, \ldots, 0)$. Then we accept $\omega=\varnothing$ and $\underline{r}_{i}:=0,(i=\overline{1, m})$. Let some coordinate $x_{j_{1}}^{\text {so }}$ take the value of unit, for example $x_{j_{1}}^{s o}=1$. Then on the right-hand side of the system (13) there are resources for further use $1-\underline{\alpha}_{i j_{1}}(i=\overline{1, m})$. Obviously, these resources are different. With a view of constructing a final solution containing a larger number of units, i.e. in order to uniform use of the remaining resources, it is necessary to assign a penalty (price) for the use of each resource. It is clear that the penalty (price) should have such property, that at reduction of the remaining resources, the penalty for their use should increase.

If $x_{j_{2}}^{s o}=1$ is selected, then on the right side of the system (13) $1-\underline{\alpha}_{i j_{1}}-\underline{\alpha}_{i j_{2}}(i=\overline{1, m})$ remains. In the general case, $1-\underline{r}_{i}(i=\overline{1, m}) \quad$ is $\quad$ on the right side, where $\underline{r}_{i}=\sum_{j \in \omega} \underline{\alpha}_{i j}(i=\overline{1, m}), \omega=\left\{j \mid x_{j}^{s o}=1\right\}$.

We note that in [13] a penalty is imposed, which increases linearly (proportional to) with decreasing righthand sides, i.e. $\underline{t}_{i}=\underline{r}_{i}(i=\overline{1, m})$ is accepted. And in this work as a penalty $\underline{t}_{i}(i=\overline{1, m}), \quad \underline{t}_{i}=1 /\left(1-\underline{r}_{i}\right)(i=\overline{1, m})$ is acc Obviously, with increasing used resources $\underline{r}_{i}(i=\overline{1, m})$, the penalty for using the remaining resources increases nonlinearly, i.e. faster than linear. Therefore, this method will be called the method of non-linearly increasing fine. In other words $\lim _{\underline{r}_{i} \rightarrow 1} t_{i}=\infty$. This $\underline{t}_{i}(i=\overline{1, m})$ provides a high price (penalty) for the use of scarce resources.

Note that the penalty in the form $\underline{t}_{i}=\frac{1}{1-\underline{r}_{i}}(i=\overline{1, m})$ was first introduced in the work for Boolean programming problems [11]. In this paper, these concepts were extended for a more general problem of partial Boolean programming 
with interval data. It should be noted that in order to fewer use of the remaining smaller resources (righthand parts of the system (13)), it is possible to increase the penalty $\underline{t}_{i}(i=\overline{1, m})$ as follows: $\underline{t}_{i}=\frac{1}{\left(1-\underline{r}_{i}\right)^{k}}(i=\overline{1, m})$, here $k$ is a fixed natural number. Computational experiments have shown that the best results are obtained mainly for $k=2$. Then the total penalty $x_{j}^{S O}=1$ for acceptance will be $\underline{q}_{j}=\sum_{i=1}^{m} \underline{\alpha}_{i j} \underline{t}_{i} \quad(j=\overline{1, N})$.

At the same time, the profit per unit of the total penalty for constructing of a suboptimistic solution to take $x_{j}^{\text {so }}=1 \quad$ will be $\bar{Q}_{j}=\bar{c}_{j} / \underline{q}_{j}(j=\overline{1, N})$. Obviously, it is necessary to choose $x_{j_{*}}^{\text {so }}=1$, where the number $j_{*}$ is determined from the following criterion:

$$
\begin{gathered}
\max _{j} \bar{Q}_{j}=\frac{\bar{c}_{j}}{\underline{q}_{j}}=\frac{\bar{c}_{j_{*}}}{\underline{q}_{j}}=\bar{Q}_{j_{*}} \text { or } \\
j_{*}=\arg \max _{j} \bar{Q}_{j}
\end{gathered}
$$

To construct a suboptimistic solution using criterion (20), it is necessary to take into account the circumstances $j_{*} \in I$ or $j_{*} \in R$. The use of these circumstances in the construction of solutions are given below. To construct a subpessimistic solution, the process is carried out similarly as mentioned above, using the following criterion:

$$
\begin{aligned}
\max _{\text {Here }} \underline{Q}_{j} & =\max _{j} \frac{\underline{c}_{j}}{\bar{q}_{j}}=\frac{\underline{c}_{j_{*}}}{\bar{q}_{j_{*}}}=\underline{Q}_{j_{*}} . \\
\bar{q}_{j} & =\sum_{i=1}^{m} \bar{\alpha}_{i j} \bar{t}_{i} \quad(j=\overline{1, N}), \bar{t}_{i}=\frac{1}{1-\bar{r}_{i}}(i=\overline{1, m}), \\
\bar{r}_{i} & =\sum_{j \in \omega} \bar{\alpha}_{i j} \quad(i=\overline{1, m}), \omega=\left\{j \mid x_{j}=1\right\} .
\end{aligned}
$$

At the beginning of the constructing process of a sub-pessimistic solution $\omega=\{\varnothing\} \quad$ and $\bar{r}_{i}:=0,(i=\overline{1, m})$, i.e. $X^{s p}=(0,0, \ldots, 0)$ are accepted. Using the criteria (20) or (21) to construct a suboptimistic or subpessimistic solution two approaches were developed, respectively. These approaches to the construct of a suboptimistic solution was presented as follows.

I approach: In the case when for the first time it is impossible to assign to an unknown $x_{j}^{S O},(j \in R)$ a unit, then for this unknown we take the possible fractional values, and for the remaining variables we assign zero.
In other words, if $j_{*} \in I$, then $x_{j_{*}}^{\text {so }}$ can take the values either 0 or 1 . If $\underline{\alpha}_{i j_{*}} \leq 1-\underline{r}_{i}(i=\overline{1, m})$, then $x_{j_{*}}^{s o}:=1$, $\underline{r}_{i}:=\underline{r}_{i}+\underline{\alpha}_{i j_{*}}, \quad(i=\overline{1, m}), \quad I:=I \backslash\left\{j_{*}\right\}$, is accepted, and if at least for one $i \quad(i=\overline{1, m}), \underline{\alpha}_{i j_{*}}>1-\underline{r}_{i}(i=\overline{1, m}), \quad x_{j_{*}}^{s o}:=0$, $I:=I \backslash\left\{j_{*}\right\}$ is accepted. If $j_{*} \in R$, then the unknown $x_{j_{*}}^{s o}$ must take any values from the interval $[0,1]$. In this case, if $\underline{\alpha}_{i j_{*}} \leq 1-\underline{r}_{i}$, for all $i \quad(i=\overline{1, m})$, then we accept $x_{j_{*}}^{s o}:=1$, $\underline{r}_{i}:=\underline{r}_{i}+\underline{\alpha}_{i j_{*}}, \quad(i=\overline{1, m}), \quad R:=R \backslash\left\{j_{*}\right\}$. And if at least for one $i \quad(i=\overline{1, m}) \quad \underline{\alpha}_{i j_{*}}>1-\underline{r}_{i}(i=\overline{1, m})$, then we accept $x_{j_{*}}^{\text {so }}=\min _{i} \frac{1-\underline{r}_{i}}{\underline{\alpha}_{i j_{*}}}, R:=R \backslash\left\{j_{*}\right\}, \quad \underline{r}_{i}:=\underline{r}_{i}+\underline{\alpha}_{i j_{*}} x_{j_{*}}^{\text {so }}$. And for the rest $j$ it is accepted $x_{j}^{s o}:=0,(j \in I \cup R)$.

Obviously, in this case, at least for one $i \quad(i=\overline{1, m})$, $\underline{r}_{i}=1$ is obtained, the process of constructing a suboptimistic solution is completed.

To continue the construction process of a suboptimistic solution $X^{\text {So }}=\left(x_{1}^{S O}, x_{2}^{s o}, \ldots, x_{N}^{S O}\right)$, we find the next number $j_{*}$ from the criteria (6) or (20). Construction process of this solution is completed, if $I=\varnothing$ and $R=\varnothing$.

Note that it is possible to construct a subpessimistic solution $\quad X^{s p}=\left(x_{1}^{s p}, x_{2}^{s p}, \ldots, x_{N}^{s p}\right)$ of problem (16)-(19) similarly to the above, only using criteria (7) or (21).

II approach: Here, in the case of $j_{*} \in I$, the first part of the I approach still stands, and in the case of $j_{*} \in R$, i.e. When the unknown $x_{j_{*}}^{\text {so }}$ should take any values from the interval $[0,1]$, we proceed as follows: if $\underline{\alpha}_{i j_{*}} \leq 1-\underline{r}_{i}$ for all $i \quad(i=\overline{1, m})$, then we accept $x_{j_{*}}^{s o}:=1, \quad \underline{r}_{i}:=\underline{r}_{i}+\underline{\alpha}_{i j_{*}}$, $(i=\overline{1, m}) \quad R:=R \backslash\left\{j_{*}\right\}$. And if it is impossible to assign a unit to an unknown $x_{j_{*}}^{\text {so }}$, i.e. at least for one $i \quad(i=\overline{1, m})$ the condition $\underline{\alpha}_{i j_{*}}>1-\underline{r}_{i}(i=\overline{1, m})$ is fulfilled, then for $j \in I$ we accept $x_{j}:=0$. And for the rest $x_{j}^{s o} \quad(j \in R)$ we construct a linear programming problem and solve it by some well-known method. Obviously, the dimension of the obtained problem will be much smaller. These circumstances are confirmed once again in computational experiments.

Finally, we will write an algorithm for constructing of a suboptimistic solution by the nonlinearly increasing penalty method (The algorithm for constructing of a subpessimistic solution is compiled similarly). 
Algorithm of the non-linearly increasing penalty method (I approach)

Step 1. Input

$N, n, \underline{a}_{i j}, \bar{a}_{i j}, \underline{c}_{j}, \bar{c}_{j}, \underline{b}_{i}, \bar{b}_{i},(i=\overline{1, m} ; j=\overline{1, N})$.

Step 2. Accept $b_{i}:=\bar{b}_{i}, \underline{\alpha}_{i j}=\frac{\underline{a}_{i j}}{b_{i}}, \quad \bar{\alpha}_{i j}=\frac{\bar{a}_{i j}}{b_{i}}$, $b_{i}:=1,(i=\overline{1, m} ; j=\overline{1, N})$.

Step 3.

$x_{j}^{\text {so }},(j=\overline{1, N}), \omega=\{\varnothing\}, \underline{r}_{i}:=0,(i=\overline{1, m}) \quad$ and $\quad$ sets $I:=\{1,2, \ldots, n\}, R:=\{n+1, n+2, \ldots N\}$.

Step 4. Compute $\quad \underline{t}_{i}=1 /\left(1-\underline{r}_{i}\right)(i=\overline{1, m})$, $\underline{q}_{j}=\sum_{i=1}^{m} \underline{\alpha}_{i j} \underline{t}_{i}, j \in I \cup R$.

Step 5. Compute $\bar{Q}_{j}=\bar{C}_{j} / \underline{q}_{j}(j \in I \cup R)$ and find $j_{*}$ from relation $j_{*}=\arg \max _{j} \bar{Q}_{j}$

Step 6. If $j_{*} \in I$ and for all $i \quad(i=\overline{1, m})$ the relation $\underline{\alpha}_{i j_{*}} \leq 1-\underline{r}_{i}$ is fulfilled, then accept $x_{j_{*}}^{\text {so }}:=1$, $\underline{r}_{i}:=\underline{r}_{i}+\underline{\alpha}_{i j_{*}}, I:=I \backslash\left\{j_{*}\right\}$ and pass to step 4 .

Step 7. If $j_{*} \in I$ and at least for one $i \quad(i=\overline{1, m})$ the relation $\underline{\alpha}_{i j_{*}}>1-\underline{r}_{i}$ is fulfilled, then accept $x_{j_{*}}^{s o}:=0, I:=I \backslash\left\{j_{*}\right\}$ and pass to step 4 .

Step 8. . If $j_{*} \in R$ and at least for any $i \quad(i=\overline{1, m})$ the relation $\underline{\alpha}_{i j_{*}} \leq 1-\underline{r}_{i}$ is fulfilled, then accept $x_{j_{*}}^{\text {so }}:=1, \underline{r}_{i}:=\underline{r}_{i}+\underline{\alpha}_{i j_{*}}, R:=R \backslash\left\{j_{*}\right\}$ and pass to step 4.

Step 9. If $j_{*} \in R$ and at least for one $i \quad(i=\overline{1, m})$, relation $\underline{\alpha}_{i j_{*}}>1-\underline{r}_{i}$ is fulfilled, then accept $x_{j_{*}}^{s o}=\min _{i} \frac{1-\underline{r}_{i}}{\underline{\alpha}_{i j_{*}}}, \underline{r}_{i}:=\underline{r}_{i}+\underline{\alpha}_{i j_{*}} x_{j_{*}}^{s o}, \quad R:=R \backslash\left\{j_{*}\right\}$ and $x_{j_{*}}^{\text {so }}:=0, \quad j \in I \cup R$.

Step 10. Compute $f^{\text {so }}:=\sum_{j=1}^{N} \bar{c}_{j} x_{j}^{s o}$.

Step 11. Print $f^{\text {so }}, x^{s o}=\left(x_{1}^{s o}, x_{2}^{s o}, \ldots, x_{N}^{s o}\right)$.

Step12. Stop.

Note that, a suboptimistic solution of the problem (1)-(4)is found by the application of the above algorithm . And to construct sub-pessimistic solution, you can use the same algorithm completely, but instead of using the criterion (20), you need to use criterion (21).

It is important to note that the algorithm for constructing suboptimistic and sub-pessimistic solutions by the second method, one can use this algorithm, but in the case of $j_{*} \in I$ and at least for one $i \quad(i=1, m)$, the relation $\underline{\alpha}_{i j_{*}}>\bar{b}_{i}$ is satisfied, then we take for $x_{j}:=0$, and for $j \in I$ but for all other non-fixed variables $j, j \in R$ we compose and solve a linear programming problem of smaller dimension. Then we add the obtained solution to the fixed coordinates of the solution.

To estimate errors of the obtained suboptimistic and suboptimistic values from the optimistic and pessimistic values, the original problem is solved as a linear programming problem and corresponding values $\bar{f}_{\text {op }}$ and $\bar{f}_{p}$ are obtained, respectively. Then the relative errors are estimated as follows:

$$
\begin{aligned}
\delta_{s o}^{1} & \leq \frac{\bar{f}_{o p}-f_{s o}^{1}}{\bar{f}_{o p}}, \delta_{s o}^{2} \leq \frac{\bar{f}_{o p}-f_{s o}^{2}}{\bar{f}_{o p}}, \\
\delta_{\text {so.sht }}^{1} \leq & \frac{\bar{f}_{o p}-f_{s o . s h t}^{1}}{\bar{f}_{o p}}, \delta_{s o . s h t}^{2} \leq \frac{\bar{f}_{o p}-f_{s o . s h t}^{2}}{\bar{f}_{o p}}, \\
\delta_{s p}^{1} \leq & \frac{\bar{f}_{p}-f_{s p}^{1}}{\bar{f}_{p}}, \delta_{s p}^{2} \leq \frac{\bar{f}_{p}-f_{s p}^{2}}{\bar{f}_{p}}, \\
\delta_{s p . s h t}^{1} \leq & \frac{\bar{f}_{p}-f_{s p . s h t}^{1}}{\bar{f}_{p}}, \delta_{s p . s h t}^{2} \leq \frac{\bar{f}_{p}-f_{s p . s h t}^{2}}{\bar{f}_{p}} .
\end{aligned}
$$

It must be noted, that in development of methods for solving problems (1)-(4), the ideas of work [9-12] were used.

\section{EXPERIMENTS}

To identify the quality of the developed algorithms in this paper, the programs of these algorithms are compiled and a number of computational experiments were carried out on problems of large dimension. Using the work [11], the coefficients of these problems are chosen as randomly twodigit or three-digit numbers as follows:

$$
\begin{gathered}
\text { I. } 0 \leq \underline{a}_{i j} \leq 99,1 \leq \bar{a}_{i j} \leq 99,1 \leq \underline{c}_{j} \leq 99, \\
\quad 1 \leq \bar{c}_{j} \leq 99,(i=\overline{1, m} ; j=\overline{1, N}) . \\
\text { II. } 0 \leq \underline{a}_{i j} \leq 999,1 \leq \bar{a}_{i j} \leq 999,1 \leq \underline{c}_{j} \leq 999, \\
\quad 1 \leq \bar{c}_{j} \leq 999,(i=\overline{1, m} ; j=\overline{1, N}) . \\
\underline{b}_{i}:=\left[\frac{1}{3} \sum_{j=1}^{N} \underline{a}_{i j}\right], \bar{b}_{i}:=\left[\frac{1}{3} \sum_{j=1}^{N} \bar{a}_{i j}\right],(i=\overline{1, m}) .
\end{gathered}
$$

Here $[\mathrm{z}]$ denotes the integer part of the number $\mathrm{z}$.

The results of the computational experiments are presented in the following tables, where for each dimension, 5 different problems were calculated. 
5 RESULTS

Table 1 - Experiments with two-digit coefficients $(N=500 ; n=300 ; m=10)$

\begin{tabular}{|l|l|l|l|l|l|}
\hline № & 1 & 2 & 3 & 4 & 5 \\
\hline $\bar{f}_{\text {op }}$ & 22948.176 & 22737.032 & 22307.446 & 22490.986 & 21982.270 \\
\hline$\underline{f}_{s o}^{1}$ & 22458.800 & 22234.909 & 21877.868 & 21908.750 & 21598.278 \\
\hline$\underline{f}_{\text {so }}^{2}$ & 22499.599 & 22244.156 & 21885.093 & 21916.256 & 21607.766 \\
\hline$\underline{f}_{\text {so.sht }}^{1}$ & 22867.500 & 22646.917 & 22175.650 & 22419.818 & 21853.667 \\
\hline$\underline{f}_{\text {so.sht }}^{2}$ & 22875.682 & 22700.419 & 22223.520 & 22438.152 & 21878.973 \\
\hline$\delta_{s o}^{1}$ & 0.021 & 0.022 & 0.019 & 0.026 & 0.017 \\
\hline$\delta_{s o}^{2}$ & 0.020 & 0.022 & 0.019 & 0.026 & 0.017 \\
\hline$\delta_{\text {so.sht }}^{1}$ & 0.004 & 0.004 & 0.006 & 0.003 & 0.006 \\
\hline$\delta_{\text {so.sht }}^{2}$ & 0.003 & 0.002 & 0.004 & 0.002 & 0.005 \\
\hline$k_{\text {so }}$ & 119 & 109 & 97 & 102 & 103 \\
\hline$k_{\text {so.sht }}$ & 108 & 97 & 93 & 102 & 100 \\
\hline $\bar{f}_{p}$ & 14039.384 & 14183.660 & 13947.478 & 13755.646 & 13584.626 \\
\hline$\underline{f}_{s p}^{1}$ & 13949.091 & 14082.000 & 13809.471 & 13609.842 & 13466.579 \\
\hline$\underline{f}_{s p}^{2}$ & 13949.091 & 14103.551 & 13824.456 & 13611.735 & 13487.778 \\
\hline$\underline{f}_{s p . s h t}^{1}$ & 13973.145 & 14121.324 & 13877.356 & 13696.894 & 13502.867 \\
\hline$\underline{f}_{s p . s h t}^{2}$ & 13980.549 & 14133.362 & 13887.259 & 13716.408 & 13507.457 \\
\hline$\delta_{s p}^{1}$ & 0.006 & 0.007 & 0.010 & 0.011 & 0.009 \\
\hline$\delta_{s p}^{2}$ & 0.006 & 0.006 & 0.009 & 0.010 & 0.007 \\
\hline$\delta_{s p . s h t}^{1}$ & 0.005 & 0.004 & 0.005 & 0.004 & 0.006 \\
\hline$\delta_{s p . s h t}^{2}$ & 0.004 & 0.004 & 0.004 & 0.003 & 0.006 \\
\hline$k_{s p}$ & 140 & 139 & 128 & 136 & 139 \\
\hline$k_{s p . s h t}$ & 143 & 138 & 129 & 136 & 135 \\
\hline
\end{tabular}

Table 2 - Experiments with two-digit coefficients $(N=1000 ; n=600 ; m=10)$

\begin{tabular}{|l|l|l|l|l|l|}
\hline № & 1 & 2 & 3 & 4 & 5 \\
\hline $\bar{f}_{\text {op }}$ & 45911.804 & 45296.379 & 44437.319 & 45092.610 & 44435.775 \\
\hline$\underline{f}_{\text {so }}^{1}$ & 44627.593 & 44136.731 & 43596.684 & 44301.667 & 43647.305 \\
\hline$\underline{f}_{\text {so }}^{2}$ & 44679.811 & 44198.527 & 43610.339 & 44358.495 & 43675.640 \\
\hline$\underline{f}_{\text {so.sht }}^{1}$ & 45828.458 & 45178.727 & 44385.097 & 45017.759 & 44376.333 \\
\hline$\underline{f}_{\text {so.sht }}^{2}$ & 45896.308 & 45217.426 & 44394.583 & 45021.415 & 44397.888 \\
\hline$\delta_{\text {so }}^{1}$ & 0.028 & 0.026 & 0.019 & 0.018 & 0.018 \\
\hline$\delta_{\text {so }}^{2}$ & 0.027 & 0.024 & 0.019 & 0.016 & 0.017 \\
\hline$\delta_{\text {so.sht }}^{1}$ & 0.002 & 0.003 & 0.001 & 0.002 & 0.001 \\
\hline$\delta_{\text {so.sht }}^{2}$ & 0.000 & 0.002 & 0.001 & 0.002 & 0.001 \\
\hline$k_{\text {so }}$ & 199 & 225 & 211 & 213 & 220 \\
\hline$k_{\text {so.sht }}$ & 183 & 211 & 193 & 196 & 25 \\
\hline
\end{tabular}


Table 2 continuation

\begin{tabular}{|l|l|l|l|l|l|}
\hline $\bar{f}_{p}$ & 27827.451 & 28181.955 & 28069.358 & 27822.487 & 27432.328 \\
\hline$\underline{f}_{s p}^{1}$ & 27642.257 & 27889.179 & 27762.000 & 27613.937 & 27139.276 \\
\hline$\underline{f}_{s p}^{2}$ & 27642.720 & 27903.243 & 27762.000 & 27630.092 & 27153.737 \\
\hline$\underline{f}_{s p . s h t}^{1}$ & 27775.275 & 28094.640 & 28007.694 & 27751.538 & 27359.500 \\
\hline$\underline{f}_{s p . s h t}^{2}$ & 27780.474 & 28127.185 & 28019.607 & 27768.076 & 27362.182 \\
\hline$\delta_{s p}^{1}$ & 0.007 & 0.010 & 0.011 & 0.007 & 0.011 \\
\hline$\delta_{s p}^{2}$ & 0.007 & 0.010 & 0.011 & 0.007 & 0.010 \\
\hline$\delta_{s p . s h t}^{1}$ & 0.002 & 0.003 & 0.002 & 0.003 & 0.003 \\
\hline$\delta_{s p . s h t}^{2}$ & 0.002 & 0.002 & 0.002 & 0.002 & 0.003 \\
\hline$k_{s p}$ & 266 & 271 & 269 & 276 & 280 \\
\hline$k_{s p . s h t}$ & 264 & 269 & 260 & 277 & 275 \\
\hline
\end{tabular}

Table 3 - Experiments with three-digit coefficients $(N=500 ; n=300 ; m=10)$

\begin{tabular}{|l|l|l|l|l|l|}
\hline$№$ & 1 & 2 & 3 & 4 & 5 \\
\hline $\bar{f}_{\text {op }}$ & 207813.440 & 204799.686 & 201112.681 & 203689.588 & 199601.713 \\
\hline$\underline{f}_{s o}^{1}$ & 203492.135 & 198601.718 & 196161.118 & 197544.935 & 193740.212 \\
\hline$\underline{f}_{s o}^{2}$ & 204080.969 & 198679.476 & 196336.007 & 197629.799 & 194101.881 \\
\hline$\underline{f}_{\text {so.sht }}^{1}$ & 207116.555 & 204110.132 & 200646.886 & 202920.037 & 198132.469 \\
\hline$\underline{f}_{\text {so.sht }}^{2}$ & 207142.991 & 204348.405 & 200734.420 & 202993.009 & 198240.447 \\
\hline$\delta_{\text {so }}^{1}$ & 0.021 & 0.030 & 0.025 & 0.030 & 0.029 \\
\hline$\delta_{\text {so }}^{2}$ & 0.018 & 0.030 & 0.024 & 0.030 & 0.028 \\
\hline$\delta_{\text {so.sht }}^{1}$ & 0.003 & 0.003 & 0.002 & 0.004 & 0.007 \\
\hline$\delta_{\text {so.sht }}^{2}$ & 0.003 & 0.002 & 0.002 & 0.003 & 0.007 \\
\hline$k_{\text {so }}$ & 120 & 115 & 105 & 110 & 112 \\
\hline$k_{\text {so.sht }}$ & 112 & 106 & 95 & 108 & 105 \\
\hline $\bar{f}_{p}$ & 141571.166 & 142834.086 & 139843.917 & 138310.900 & 136465.802 \\
\hline$\underline{f}_{s p}^{1}$ & 140092.684 & 141415.095 & 138470.466 & 136071.083 & 134879.129 \\
\hline$\underline{f}_{s p}^{2}$ & 140104.789 & 141629.340 & 138705.641 & 136149.312 & 134982.791 \\
\hline$\underline{f}_{s p . s h t}^{1}$ & 140808.383 & 142269.891 & 139219.236 & 137639.519 & 135628.630 \\
\hline$\underline{f}_{s p . s h t}^{2}$ & 140849.800 & 142344.442 & 139375.527 & 137692.414 & 135778.228 \\
\hline$\delta_{s p}^{1}$ & 0.010 & 0.010 & 0.010 & 0.016 & 0.012 \\
\hline$\delta_{s p}^{2}$ & 0.010 & 0.008 & 0.008 & 0.016 & 0.011 \\
\hline$\delta_{s p . s h t}^{1}$ & 0.005 & 0.004 & 0.004 & 0.005 & 0.006 \\
\hline$\delta_{s p . s h t}^{2}$ & 0.005 & 0.003 & 0.003 & 0.004 & 0.005 \\
\hline$k_{s p}$ & 139 & 136 & 133 & 135 & 139 \\
\hline$k_{s p . s h t}$ & 141 & 135 & 131 & 133 & 137 \\
\hline
\end{tabular}


Table 4 - Experiments with three-digit coefficients $(N=1000 ; n=600 ; m=10)$

\begin{tabular}{|l|l|l|l|l|l|}
\hline № & 1 & 2 & 3 & 4 & 5 \\
\hline $\bar{f}_{\text {op }}$ & 416772.431 & 407262.286 & 400559.019 & 410320.331 & 402729.978 \\
\hline$\underline{f}_{\text {so }}^{1}$ & 403111.858 & 396721.293 & 390388.890 & 401217.913 & 392177.833 \\
\hline$\underline{f}_{\text {so }}^{2}$ & 403492.387 & 396912.010 & 390687.146 & 401814.400 & 392573.481 \\
\hline$\underline{f}_{\text {so.sht }}^{1}$ & 416005.141 & 406270.986 & 399687.804 & 409494.837 & 401871.992 \\
\hline$\underline{f}_{\text {so.sht }}^{2}$ & 416238.934 & 406405.856 & 399782.798 & 410041.511 & 402047.775 \\
\hline$\delta_{\text {so }}^{1}$ & 0.033 & 0.026 & 0.025 & 0.022 & 0.026 \\
\hline$\delta_{\text {so }}^{2}$ & 0.032 & 0.025 & 0.025 & 0.021 & 0.025 \\
\hline$\delta_{\text {so.sht }}^{1}$ & 0.002 & 0.002 & 0.002 & 0.002 & 0.002 \\
\hline$\delta_{\text {so.sht }}^{2}$ & 0.001 & 0.002 & 0.002 & 0.001 & 0.002 \\
\hline$k_{\text {so }}$ & 218 & 237 & 214 & 226 & 232 \\
\hline$k_{\text {so.sht }}$ & 195 & 223 & 204 & 214 & 210 \\
\hline $\bar{f}_{p}$ & 280754.495 & 284249.634 & 282822.257 & 280536.958 & 277027.700 \\
\hline$\underline{f}_{s p}^{1}$ & 278290.868 & 280818.009 & 279785.821 & 278534.584 & 274033.651 \\
\hline$\underline{f}_{s p}^{2}$ & 278305.366 & 280972.875 & 279895.739 & 278678.161 & 274132.534 \\
\hline$\underline{f}_{s p . s h t}^{1}$ & 279728.741 & 283343.339 & 282041.765 & 279638.956 & 276478.038 \\
\hline$\underline{f}_{s p . s h t}^{2}$ & 280001.797 & 283362.542 & 282256.459 & 279670.043 & 276552.316 \\
\hline$\delta_{s p}^{1}$ & 0.009 & 0.012 & 0.011 & 0.007 & 0.011 \\
\hline$\delta_{s p}^{2}$ & 0.009 & 0.012 & 0.010 & 0.007 & 0.010 \\
\hline$\delta_{s p . s h t}^{1}$ & 0.004 & 0.003 & 0.003 & 0.003 & 0.002 \\
\hline$\delta_{s p . s h t}^{2}$ & 0.003 & 0.003 & 0.002 & 0.003 & 0.002 \\
\hline$k_{\text {sp }}$ & 265 & 274 & 265 & 279 & 279 \\
\hline$k_{\text {sp.sht }}$ & 263 & 269 & 261 & 278 & 273 \\
\hline
\end{tabular}

\section{DISCUSSION}

As will be seen from the above tables it is clear that the suboptimistic and subpessimistic values obtained by 1 and 2 methods of the objective function differ from each other (non-linearly increasing penalty). Taking into account that in the second approach the apparatus of the linear programming method is being used, which gives the best result both for the 1-st and the 2-nd methods. The more practical method can be considered the 2-nd method corresponding to the 2nd approach. Because this algorithm works faster than the application of linear programming apparatus. The above experiments of the 1 -st method show that the relative errors of the suboptimistic and sub-pessimistic values of the objective function from the upper and lower bounds of the suboptimistic and pessimistic values for the 1st method vary within the limits of $0.016-0.033$ and 0.006-0.016, and for the 2-nd method 0.000-0.007 and

(C) Mamedov K. Sh., Mammadli N. O., 2018

DOI 10.15588/1607-3274-2018-3-7
$0.002-0.006$ respectively. And this means that using the methods developed in this article, the relative errors are not greater than $3.3 \%$. On the other hand, in order to apply the 2-nd approach for constructing of suboptimistic and subpessimistic solutions for problems with two-digit coefficients, for the 1-st method on the average remains 106 and 136 variables out of 500 respectively, 214 and 272 out of 1000 variables respectively, and to construct suboptimistic and subpessimistic solutions for the 2nd method, the remaining number of variables is 100 and 136 of 500, 198 and 269 of 1000 variables. The above experiments once again confirm the efficiency and practicality of the developed methods in this work.

\section{CONCLUSIONS}

Proceeding from the above, the following conclusions may be drawn. In this article effective methods for solving problems of mixed Boolean programming with interval data have been developed. As far as we know, the problem of 
mixed Boolean programming with interval data has not yet been studied in detail.

To this end, the concepts of optimistic, pessimistic, suboptimistic and subpessimistic solutions were introduced. Using these concepts, two types of methods were proposed. Computational experiments have showed that the method of nonlinearly increasing penalty in most cases exceeds the first method. Therefore, to solve practical problems, it is necessary to solve both methods and choose the best.

\section{ACKNOWLEDGEMENTS}

The work was carried out within the framework of the state budget research work of the Institute of Control Systems of ANAS "Development of solutions methods for solving algorithms and software for solving various classes of mixed integer programming problems" (State Registration No. 0101 Az 00736). We note that a particular case of this paper was considered by the authors in [7].

\section{REFERENCES}

1. Gary M., Johnson D. M. Vichislitelniye mashini i trudnoreshayemiye zadaci. Mir, 1982, $416 \mathrm{p}$.

2. Aho A., Hopcroft J., Ullman J. Postroyeniye i analiz vichislitelnix alqoritmov. Mir, 1979, $536 \mathrm{p}$.

3. Libura M. Integer programming problems with inexact objective function, Control And Cybernetics, 1980, Vol. 9, No. 4, pp. 189-202.

4. Roshin V. A., Semenova N. V., Sergiyenko I. V. Dekompozicionniy podxod $\mathrm{k}$ resheniyu nekotorix zadac celocislennoqo proqrammirovaniya $\mathrm{s}$ netocnimi dannimi,
Journal Vicislitelnoy Matematiki i Matematiceskoy Fiziki, 1990, Vol. 30, No. 5, pp. 786-791.

5. Devyaterikova M. V., Kolokolov A. A., Kolosov A. P. Alqoritmi perebora L-klassov dla bulevoy zadaci o ryukzake s intervalnimi dannimi. Materiali III Vserossiyskoy konferencii "Problemi optimizacii I ekonomiceskoye prilojeniye". Omsk, Izd-vo Ом ГТУ, 2006, Р. 87.

6. Emelichev V. A., Podkopaev D. P. Quantitative stability analysis for vector problems of $0-1$ programming, Discrete Optimitation, 2010, No. 7, pp. 48-63.

7. Mamedov K. Sh., Mamedli N. O. Metodi postroyeniya suboptimisticeskoqo i subpessimisticeskoqo resheniy chasticnoBulevoy zadaci o ranche $\mathrm{s}$ intervalnimi dannimi, Izv. NAN Azerbaijan, 2016, No. 6, pp. 6-13.

8. Mamedov K. Sh., Mamedova A. H. Ponyatiya suboptimisticeskoqo I subpessimisticeskoqo resheniy i postroyeniye ix $\mathrm{v}$ intervalnoy zadace Bulevoqo proqrammirovaniya, Radio Electronics, Computer Science, Control, 2016, No. 3, pp. 99-107.

9. Martello S., Toth P. Knapsack problems, Algorithm and Computers implementations. Chichster, John Wiley \& Sons, 1990, $296 \mathrm{p}$.

10. Kovalev M. M. Diskretnaya optimizaciya (celocislennoye proqrammirovaniye). Moscow, U.RSS, 2003, 192 p.

11. Babayev J. A. Mamedov K. Sh., Mextiyev M. Q. Metodi postroyeniya suboptimalnix resheniy mnoqomernoy zadaci o rance, Journal Vicislitelnoy Matematiki i Matematiceskoy Fiziki, 1978, Vol.28, No. 6, pp. 1443-1453.

12. Alefeld Q., Herzberger J. Vvedeniye v intervalniye vicisleniya Translation from eng. Moscow, Mir, 1987, $360 \mathrm{p}$.

13. Toyoda Y. A simplified algorithm for obtaining approximate solutions to zero-one programming problems, Management Science, 1975 , No. 12, pp. 1417-1427.

УДК 519. 852.6

\section{ДВА МЕТОДА ДЛЯ ПОСТРОЕНИЯ СУБОПТИМИСТИЧЕСКОГО И СУБПЕССИМИСТИЧЕСКОГО РЕШЕНИЙ ИНТЕРВАЛЬНОЙ ЗАДАЧИ ЧАСТИЧНО-БУЛЕВОГО ПРОГРАММИРОВАНИЯ}

Мамедов К. Ш. - д-р физ.-мат. наук, профессор Бакинского Государственного Университета и зав. отделом Института Систем Управления НАН Азербайджана, Азербайджан, Баку.

Мамедли Н. О. - докторант Института Системных Управлений НАН Азербайджана, Азербайджан, Баку.

\section{АННОТАЦИЯ}

Актуальность. Рассмотрена интервальная задача частично-Булевого программирования, имеющая многочисленные экономические применения. Объектом исследования являлась модель целочисленного программирования.

Цель работы. Разработка методов построения субоптимистического и субпессимистического решений интервальной задачи частично-Булевого программирования.

Метод. Введены два метода для построения субоптимистического и субпессимистического решений задач частичноБулевого программирования с интервальными исходными данными. Эти методы основаны на некоторой экономической интерпретации рассмотренной модели.

В первом методе введен критерий выбора неизвестных для присвоения значений, который основан по принципу максимальности прибыли на каждую единицу расхода. Поскольку коэффициенты задачи являются интервалами, выбраны две стратегии: оптимистическое и пессимистическое. В оптимистической стратегии используется идея выбора неизвестных, которая соответствует максимальности отношения соответствующей максимальной прибыли на минимальный расход. А в пессимистической стратегии использована идея максимальности отношения минимальной прибыли на максимальный расход.

Во втором методе введено понятие нелинейно-возрастающего штрафа (цены) за использование единицы оставшихся ресурсов т.е. в правой части ограниченный.

Учитывая принципы вышеуказанных первого и второго методов с использованием этого понятия штрафа (цены), разработаны методы построения субоптимистического и субпессимистического решений.

Результаты. Разработаны алгоритмы построения субоптимистического и субпессимистического решений интервальной задачи частично-Булевого программирования. 
Выводы. Составлен программный комплекс для построения субоптимистического и субпессимистического решений интервальной задачи частично-Булевого программирования. Проведен ряд вычислительных экспериментов над случайными задачами различной размерности.

КЛЮЧЕВЫЕ СЛОВА: интервальная задача частично-Булевого программирования, оптимистическое, пессимистическое, субоптимистическое и субпессимистическое решения, верхняя и нижняя границы, погрешности, вычислительный эксперимент.

\section{УДК 519.852.6}

\section{ДВА МЕТОДУ ДЛЯ ПОБУДОВИ СУБОПТІМІСТІЧЕСКОГО І СУБПЕССІМІСТІЧЕСКОГО РІШЕНЬ} ІНТЕРВАЛЬНОГО ЗАВДАННЯ ЧАСТКОВО-БУЛЕВОГО ПРОГРАМУВАННЯ

Мамедов К. Ш. - д-р фіз.-мат. наук, професор Бакинська Державного Університету та зав. від-ділом Інституту Систем Управління НАН Азербайджану, Азербайджан, Баку.

Мамедлі Н. О. - докторант Інституту системного Управлінь НАН Азербайджану, Азербайджан, Баку.

\section{АНОТАЦІЯ}

Актуальність. Розглянута интервальна задача частково-Булевого програмування, що має численні економічні застосування. Об'єктом дослідження була модель цілочисельного програмування.

Мета роботи. Розробка методів побудови субоптимістичного і субпессимістичного рішень інтервального завдання частково-Булевого програмування.

Метод. Введено два методи для побудови субоптимістичного і субпессимістичного рішень задач частково-Булевого програмування 3 інтервальними вихідними даними. Ці методи засновані на деякій економічній інтерпретації розглянутої моделі.

У першому методі введений критерій вибору невідомих для присвоєння значень, який заснований за принципом максимальності прибутку на кожну одиницю витрат. Оскільки коефіцієнти завдання є інтервалами, обрані дві стратегії: оптимістичний і песимістичний. В оптимістичній стратегії використовується ідея вибору невідомих, яка відповідає максимальності відносини відповідної максимального прибутку на мінімальну витрату. А в песимістичній стратегії використана ідея максимальності відносини мінімального прибутку на максимальній витраті.

У другому методі введено поняття нелінійно-зростаючого штрафу (ціни) за використання одиниці ресурсів, що залишилися тобто в правій частині обмежений.

3 огляду на принципи вищевказаних першого і другого методів з використанням цього поняття штрафу (ціни), розроблені методи побудови субоптимістичного і субпессимістичного рішень.

Результати. Розроблено алгоритми побудови субоптимістичного і субпессимістічного рішень інтервального завдання частково-Булевого програмування

Висновки. Складено програмний комплекс для побудови субоптимістичного і субпессимістичного рішень інтервального завдання частково-Булевого програмування. Проведено ряд обчислювальних експериментів над випадковими завданнями різної розмірності.

КЛЮЧОВІ СЛОВА: інтервальна задача частково-Булевого програмування, оптимістичне, песимістичне, субоптимістичне і субпессимістичне рішення, верхня і нижня межі, похибки, обчислювальний експеримент.

\section{ЛІТЕРАТУРА/ЛИТЕРАТУРА}

1. Гэри М. Вычислительные машины и труднорешаемые задачи / М. Гэри, Д. М. Джонсон. - Мир, 1982, 416 с.

2. Ахо А. Построение и анализ вычислительных алгоритмов / А. Ахо, Дж. Хопкрофт, Дж. М. Ульман. - Мир, 1979. $-536 \mathrm{c}$.

3. Libura M. Integer programming problems with inexact objective function / M. Libura // Control And Cybernetics. 1980. - Vol. 9, № 4. - P. 189-202.

4. Рощин В. А. Декомпозиционный подход к решению некоторых задач целочисленного программирования с неточными данными / В. А. Рощин, Н. В. Семенова, И. В. Сергиенко // Журнал Вычислительной Математики и Математической Физики. - 1990. - Т. 30, № 5. С. 786-791.

5. Девятерикова M. В. Алгоритмы перебора L-классов для булевой задачи о рюкзаке с интервальными данными М. В. Девятерикова, А. А. Колоколов, А. П. Колосов // Материалы III Всероссийской конференции «Проблемы оптимизации и экономическое приложение». - Омск : Изд-во Ом ГТУ, 2006. - С. 87.

6. Emelichev V. A. Quantitative stability analysis for vector problems of 0-1 programming / V. A. Emelichev, D. P. Podkopaev // Discrete Optimitation. - 2010. - № 7. - P. 48-63.

7. Мамедов К. Ш. Методы построения субоптимистического и субпессимистического решений частично-
Булевой задачи о ранце с интервальными данными / К. Ш. Мамедов, Н. О. Мамедли // Изв. НАН Азербайджана. - 2016. - № 6. - С. 6-13.

8. Мамедов К. Ш. Понятия субоптимистического и субпессимистического решений и построение их в интервальной задаче Булевого программироания / К. Ш. Мамедов, А. Г. Мамедова // Радиоэлектроника, информатика, управление. - 2016. - № 3. - С. 99-107.

9. Martello S. Knapsack problems, Algorithm and Computers implementations / S. Martello, P. Toth. - Chichster : John Wiley \& Sons, 1990. - 296 p.

10. Ковалев М. М. Дискретная оптимизация (целочисленное программирование) / М. М. Ковалев. - М. : УРСС, 2003. -192 c.

11. Бабаев Дж. А. Методы построения субоптимальных решений многомерной задачи о ранце / Дж. А. Бабаев, К. Ш. Мамедов, М. Г. Мехтиев // Журнал Вычислительной Математики и Математической Физики. - 1978. Т. 28, № 6. - С. 1443-1453.

12. Алефельд Г. Введение в интервальные вычисления / Г. Алефельд, Ю. Херцбергер. - Пер. с англ. - М. : Мир, 1987. $-360 \mathrm{c}$.

13. Toyoda Y. A simplified algorithm for obtaining approximate solutions to zero-one programming problems / Y. Toyoda // Management Science. - 1975. - № 12. - C. 1417-1427. 